\title{
STRATEGI LURAH DALAM PENINGKATAN PENCAPAIAN PAJAK BUMI DAN BANGUNAN PADA KELURAHAN WAY DADI KECAMATAN SUKARAME BANDAR LAMPUNG
}

\author{
Oleh: \\ Sophan Syaiful ${ }^{1}$ \\ Dain Hermawan ${ }^{2}$ \\ Program Studi Manajemen Universitas Mitra Indonesia Lampung ${ }^{1}$ \\ Program Studi Administrsi Bisnis, Universitas Tulang Bawang Lampung ${ }^{2}$ \\ e-Mail: rachmatandfamily@gmail.com
}

\begin{abstract}
ABSTRAK
Pajak Daerah dan Peraturan Daerah Kota Bandar Lampung Nomor 05 Tahun 2009 tentang Perubahan Atas Peraturan Daerah Kota, Nomor 03 Tahun 2008 tentang Organisasi dan Tata Kerja Dinas Daerah Kota Bandar Lampung, dalam upaya terealisasinya pembangunan sebagai wujud kesadaran dalam kehidupan berbangsa dan bernegara.

Penelitian merupakan suatu cara ilmiah yang digunakan untuk mendapatkan data dengan tujuan untuk menemukan jawaban, untuk membuktikan sesuatu hal untuk memecahkan masalah. Adapun penelitian ini menggunakan metode kuantitatif.

Berdasarkan perhitungan diatas, diketahui $r$ hitung $=0,851$, dan $r$ tabel 0.602, maka terdapat hubungan antara Strategi Lurah dalam peningkatan pencapaian Pajak Bumi dan Bangunan yang sangat kuat. Hal ini sejalan dengan pendapat Sugiyono (2011:184) bahwa kocfisien korelasi tersebut berada pada interval koefisien 0,8-1,0 dan termasuk tingkat hubungan yang sangat kuat.

Selanjutnya untuk melihat besarnya pengaruh diperoleh dari besarnya Koofisien penentu (Kp). $\mathrm{Kp}=0,851 \times 100 \%$, dengan demikan besarnya Kp adalah 72,4\%, hal ini berarti 72,4\%

Peningkatan Pajak Bumi dan Bangunan ditentukan oleh Strategi Lurah, sisanya sebesar 27,6\%, ditentukan oleh faktor lain.
\end{abstract}

Disarankan agar Lurah lebih mengayomi masyarakat hingga merasa tidak terbebani dengan adanya pembayaran PBB.

Kata kunci: strategi, peningkatan pencapaian, pajak bumi bangunan, kelurahan Way Dadi Bandar Lampung

\section{PENDAHULUAN}

\section{A. Latar Belakang}

Penerimaan utama negara, yaitu

pajak digunakan untuk membiayai pengeluaran-pengeluaran pemerintah serta pembangunan. Untuk meningkatkan pencapaian target penagihan Pajak Bumi dan Bangunan (PBB), kelurahan Way Dadi Bandar Lampung menggunakan strategi 
door to door, atau dengan menurunkan aparatnya ke rumah setiap wajib pak. Dan setiap perangkat kelurahan hingga ketua RT diberdayakan untuk terjun langsung melakukan penagihan PBB di wilayah kerja masing-masing.

Pelaksansan pembangunan baik dalam jangka pendek, jangka menengah dan jangka panjang wajib dilaksanakan oleh Pemerintah selaku Ekskutif atau pelaksana dalam pembangunan bangsa, dalam konteks pembangunan dapat direalisasikan manakala adanya dukungan atau antisipasi nyata masyarakat dalam pembangunan tersebut, sebagai contoh nyata pada Kelurahan Way Dadi yang berbentuk pada tanggal 17 September 2012, dengan SK. Perda. No. 04 Th 2001, dengan luas wilayah 187 Hektar, yang berada di wilayah Kecamatan Sukarame, Kota Bandar Lampung, berdasarkan Undang-undang No. 28 Tahun 2009 tentang Pajak Daerah. Adanya kewajiban masyarakat atas warga di dalam kerelaan membayar Pajak Bumi dan Bangunan (PBB), Retrebusi Daerah dan SK. Menteri dalam Negeri NO. 43. Tahun 1999 tentang Sistam dan Prosedur Administrasi.

Pajak Daerah dan Peraturan Daerah Kota Bandar Lampung Nomor 05 Tahan 2009 tentang Perubahan Atas Peraturan Daerah Kota, Nomor 03 Tahun 2008 tentang Organisasi dan Tata Kerja Dinas Daerah Kota Bandar Lampung, dalam upaya terealisasinya pembangunan sebagai wujud kesadaran dalam kehidupan berbangsa dan bernegara.

Peran serta masyarakat di dalam Pembangunan sangatlah penting, guna menciptakan kesadaran dan kerelaan di dalam membayarkan pajak bumi dan bangunanyang merupakan salah satu sumber utama atau penghasilan primadona Pemerintah Kelurahan / Desadalam upaya terjamin dan terselenggaranya rencana, pelaksanaan pembangunan di Negara kita, sangat dibutuhkan kerja keras, dan perencanaan yang baik serta program strategis (strategis program) dalam upaya asumsi bahwa sasaran pembangunan dapat direalisasikan sesuai dengan harapan yang telah direncanakan.

Pajak Bumi dan Bangunan sebagai salah satu kontribusi nyata masyarakat dalam pembangunan daerahnya masingmasing sebagai pemasukan primadona (Favorite Income) harus digalakkan dan terus menerus oleh pemerintah Kelurahan sebagai ujung tombak dalam otoritas Pemerintah Daerah khususnya di Kota Madya Bandar Lampung, dalam upaya pengumpulan Pajak Bumi dan Bangunan (PBB), yang sering mengalami dukungan dan hambatan-hambatan dilapangan.

\section{B. Identifikasi Masalah}

Berdasarkan latar belakang yang telah diuraikan diatas, maka penulis melakukan mengidentifikasikan masalahmasalah sebagai berikut:

1. Bagaimana Strategi Lurah dalam meningkatkan pencapaian Pajak Bumi dan Bangunan (PBB) di Kelurahan Way dadi Kecamatan Sukarame Bandar Lampung.

2. Apa saja yang dapat mendukung dan menghambat Lurah dalam meningkatkan pencapaian Pajak Bumi dan Bangunan (PBB) di Kelurahan Way Dadi Kecamatan Sukarame Bandar Lampung.

3. Bagaimana Strategi Lurah dengan hasil pencapaian pengumpulan Pajak Bumi dan Bangunan.

\section{Perumusan Masalah}

Bagaimana stratgi Lurah dalam mningkatkan pencapaian Pajak Bumi 
dan Bangunan (PBB) di Kelurahan

Way Dadi Kecamatan Sukarame

Bandar Lampung?

\section{Tujuan Penelitian}

Adapun tujuan yang ingin dicapai dari penelitian ini adalah untuk mengetahui apakah strategi Lurah dalam peningkatan pencapaian Pajak Bumi dan Bangunan.

\section{E. Kegunaan Penelitian}

Setiap penelitian tentunya akan dapat memberikan berbagai manfaat bagi semua orang yang membutuhkan informasi tentang masalah yang penulis teliti, adapun kegunaan dari penelitan ini adalah:

1. Penelitian ini akan mengetahui Strategi Lurah Pencapaian Pajak Buni dan Bangunan.

2. Penelitian ini dapat memberikan kontribusi, faktor apa saja yang mendukung dalam upaya pencapaian (target) Pendapatan Pajak Bumi dan Bangunan.

3. Penelitian ini dapat memberikan kontribusi kepada pihak terkait dalam upaya memberikan solusi dan suksesnya pencapaian target Pendapatan Bumi dan Bangunan khususnya pada tingkat Kelurahan.

\section{F. Hipotesis}

Menurut Sutrisno Hadi, yang dimaksud dengan hipotesis adalah "dugaan sementara yang meningkatkan benar atau mungkin juga salah. Dia akan ditolak jika salah satu palsu, dan akan diterima jika fakta-fakta pembuktiannya benar", ( Sutrisno Hadi, 1981: 63)

Berdasarkan pendapat diatas maka hipotesis dalam penelitian ini adalah : "Apabila strategi Lurah tepat maka peningkatan Pajak Bumi dan Bangunan akan tercapai ".

\section{LANDASAN TEORI}

A. Pengertian Strategi

Menurut seorang ahli (Triton : 2007), Mendefinisikan strategi berasal dari bahasa Yunani, yaitu: "Strategos". Kata "Strategos" ini berasal dari kata "stratos" yang berarti militer dan " $a g$ " yang artinya memimpin. Kata strategi dalam bidang manajemen yang didefinisikan sebagai semua keputusan bisnis dan bagaimana cara atau upaya untuk mencapai sasaran (target) yang diinginkan. Secara umum strategi dapat didefinisikan sebagai kumpulan pilihan kritis untukk perencanaan dan penerapan serangkaian rencana tindakan dan alokasi sumber daya, yang penting dalam tujuan dasar hendak dicapai dan sasaran (target) dengan memperhatikan dan mempertimbangkan keunggulan yang kompotitif, komparatif, dan sinergis yang ideal secara berkelanjutan, sebagai arah haluan, cakupan, dan perspektif jangka panjang yang ideal dan individu ataupun organisasi.

Sedangkan menurut Henry Mintzberg, James Brian Quuinn, Jhon Voyer (1995). The Strategi Process. Prentice-Hall, Inc. Mendefinisikan Strategi sebagai $5 \mathrm{P}$, yaitu : Strategi Sebagai Perspektif, Strategi sebagai posisi, strategi sebagai perencanaan, strategi sebagai "Penipuan" (ploy) yaitu maslihat rahasia. Sebagai perspektif, dimana strategi dalam membentuk misi, menggambarkan perspektif kepada semua aktivitas. Sebagai Posisi, dimana dicari pilihan untuk bersaing.

Sebagai perencanaan, dalam hal ini strategi dapat menentukan tujuan yang hendak dicapai oleh perusahaan atau organisasi. Strategi sebagai pola kegiatan, 
dimana dalam strategi di bentuk suatu pola, yaitu umpan balik dan penyesuaian.

Sedangkan menurut W.F Glueck dn L.R Jauch, dalam bukunya "Manajemen strategi dan Kebijakan Perusahaan atau Organisasi" mendefinisikan strategi sebagai rencana yang disatukan, luas dan berintegrasi yang menghubungkan keunggulan strategi organisasi / perusahaan dengan tantangan lingkungan, yang dirancang utuk memastikan bahwa tujuan utama dari perusahaan dapat dicapai melalui pelaksanaan yang tepat oleh organisasi.

\section{B. Langkah - Langkah Perencanaan Strategi}

Menurut Kolter dan Amstrong (2008) menggambarkan langkah - langkah perencanaan strategi sebagai berikut :

1. Mendefinisikan misi organisasi atau perusahaan

Langkah awal mengembangkan pertanyaan misi, yaitu pernyataan tujuan organisasi/perusahaan tentang tujuan yangingin di peroleh organisasi/perusahaan dalam lingkungan yang lebih besar. Pernyataan tersebut harus berorientasi pasar dan di definisikan berdasarkan kebutuhan pelanggan, misi lembaga harus dapat memuaskan kebutuhan pelanggan. Penyampaian misi ini hendaknya tidak terlalu sempit tetapi juga tidak terlalu luas. Misi harus spesifik dan realis serta sesuai dengan lingkungan yang sesuai.

2. Menentukan tujuan dan sasaran lembaga

Misi harus dijabarkan menjadi tujuan-tujuan yang diperinci untuk setiap tingkat manajemen. Tujuan perusahaan ini mencakup tujuan bisnis dan tujuan fungsional. Tujuan bisnis adalah mengembangkan produk yang lebih bik sesuai dengan kebutuhan dan keinginan pelanggan. Adapun tujuan fungsional adalah menjalankan proses produksi secara efisien. Tujuan-tujuan tersebut menjadi tujuan pemasaran saat ini, untuk melanjutkan merancang strategi yang handal dalam pencapaian tujuan.

3. Merancang portofolio usaha (Bussines)

Portofolio bisnis adalah kumpulan bisnis dan produk yang membentuk lembaga. Portofolio bisnis harus sesuai dengan kekuatan dan kelemahan lembaga untuk meraih peluang bisnis.

Perencanaan portofolio organisasi / bisnis terdiri atas dua tahap, yaitu:

a. Lembaga harus menganalisis portofolio bisnis terkini yang memiliki peluang bagi lembaga untuk lebih berkembang dan memutuskan bisnis yang harus mendapatkan perhatian utama dan bisnis yang kurang menguntungkan.

b. Perusahaan harus membentuk portofolio masa depan dengan mengembangkan strategi pertumbuhan dan pengurangan.

4. Merencanakan Koordinasi dan Strategi Fungsional Lain

Langkah terakhir dalam perencanaan strategi adalah analisis portofolio, yaitu proses yang digunakan manajemen untuk mngevaluasi produk dan usaha / bisnis lembaga. Dengan kata lain, pertama-tama Lurah menyusun strategi organisasi usaha/ Bisnis unit (SBU). strategi organisasi 
usaha/ Bisnis unit adalah unit lembaga yang mempunyai misi dan tujuan terpisah serta dapat direncanakan serta independent dan usaha/bisnis dari organisasi atau perusahaan lain.

Sementara definisi kata Lurah adalah berdasarkan SK. Bpk. Walikota Bandar Lampung Nomor : 821.123./06/III/25./2014 tentang Lurah Way Dadi di Kecamatan Sukarame, dan Lurah adalah sebuah jabatan pada struktur tingkat Kelurahan di bawah koordinasi Kecamatan dan berada dalam wilayah Kota Madya, atau dapat dikatakan bahwa lurah adalah pimpinan pada satu kelurahan yang mengatur dan mengkoordinasi jajaran dan lingkungannya dalam menuju pencapaian kesejahteraan bersama dan di bawah koordinasi seorang camat pada satu wilayah Kecamatan di Sukarame.

Jadi dapat diambil satu pengartian bahwa strategi lurah adalah segala upaya dan kebijakan yang telah direncanakan oleh seorang Lurah dalam mencapai satu tujuan yang telah di tetapkan demi kesejahteraan dan pembangunan di lingkungannya.

Strategi Lurah dan kebijakankebijakan, tentu tidak terlepas dari Perencanaan (planning), dan perencanaan mempunyai arti penting dalam berbagai kegiatan yang akan dilaksanakan dalam upaya pencapaian tujuan yang optimal.

Perencanaan merupakan sebagai kegiatan awal dalam setiap tindakan yang akan dilaksanakan nanti, apakah itu akan dilaksanakan secara tertulis, atau hanya dalam pemikiran, maka perencanaann itu sendiri ada di dalam strategi, maka pentingnya perencanaan sebagai bagian tidak terpisahkan di dalam strategi arah dalam mencapai tujuan.
Sementara pengertian atau definisi Perencanaan menurut Charles E Meriam, dalam bukunya A Reader in Planning Theory, menerangkan bahwa : "Planning is an organized effort to utilize social intelegence in the determination and national policies" (perencanaan merupakan suatu usaha yang terorganisasi dalam menggunakan pemikiran-pemikiran dari beberapa orang dalam menentukan kebijakan-kebijakan nasional).

Sedangkan menurut Stephen P. Robbins mengemukakan "Planning is determining in advance the objectives to be accome plished and the means by which these objectives are to be attained" (perencanaan adalah penentuan dalam bagaimana kemajuan pencapaian tujuantujuan itu diperoleh dan merupakan alat dalam pencapaian tujuan).

Sementara menurut pendapat Ralph C Davis, Allah C. Filly, 1962, mengemukkan "Planning is the work of determining and specifying objectives, policies and budgets" (Perencanaaan adalah sebagai pekerjaan untuk penentuan dan penetapan tujuan-tujuan, kebijakankebijakan, program, hubungan-hubungan organisasi, prosedur dan anggaran).

Di dalam perencanaan ada beberapa pendekatan, antara lain, pendekatan perencanaan dengan pendekatan yang disebut dengan Performance Inprovement Planning (PIP), yang oleh lembaga administrasi negara diterjemahkan menjadi perencanaan peningkatan kinerja (prestasi kerja). Teknik ini mula-mula dikembangkan oleh Perserikatan Bangsa Bangsa (PBB) dan di perkenalkan oleh Dr. Fouad Sherif (Lembaga Administratif Negara, Perencanaan Peningkatan Kinerja, 1993). 
Perencanaan dengan pendekatan PIP, ini lebih menekankan kepada tujuan jangka pendek (1tahun) sebagai suatu prestasi kerja yang ingin dicapai oleh seorang pejabat ini menyuarakan perencanaan yang terkoordinasi, berarti memanfaatkan sumber-sumber yang ada.Tujuan jangka panjang adalah lahir dari tugas pokok dan fungsi unit yang dipimpin oleh pejabat yang bersangkutan.

Dari tugas pokok dan fungsi yang dikaji, manakah yang sesusai dengan Program pembangunan 5 tahun yang sedang dikerjakan, maupun yang mendesak untuk ditangani. Dari pengkajian ini, lahirlah tujuan jangka panjang, yang kemudian dijabarkan menjadi beberapa tujuan jangka pendek. Untuk dikinerrjakan dalam waktu 1 tahun mendatang, karena dianggap yang paling mendesak dan mendasar.

Teknik perencanaan dengan pendekatan PIP ini, diwarnai oleh pemanfaatan kekuatan penghambat dan kekuatan pendorong, sebagai kekuatan kunci untuk membuat perencanaan yang berdasarkan kepada teori Kurt Lewin (Lembaga Administrasi, perencanaan peningkatan Kinerja. Materi Diklat Jenjang SEPADYA, 1992). Teori tersebut dikenal dengan teori FFA (Force Field Analysis) atau teori analisi medan kekuatan.

Begitu juga dalam strategi lurah, yang didalamnya ada perencanaan yang matang dalam peningkatan pencapaian target pengumpulan Pajak Bumi dan Bangunan (PBB), antara lain :

1. Penyampaian SPPT PBB langsung kepada Wajib pajak (WP) dengan bekerja sama dangan Rukun Tetangga (RT) dan pembantu kolektor pajak Bumi dan Bangunan (PBB).
2. Himbauan melalai surat edaran untuk segera melunasi PBB Kepada Wajib Pajak (WP), dengan mengingatkan jatuh tempo.

3. Semester kedua (tiga bulan kedua) melakukan penagihan secara berkoordinasi dengan ketua RT, (dengan istilah jemput Bola) di bantu dengan pembantu kolektor.

4. Setiap pelayanan di Kantor Kelurahan harus melampirkan tanda lunas PBB dari Bank Lampung.

5. Jika belum bayar PBB, saat pelayanan dikantor kelurahan, bisa bayar langsung, PBB di kantor kelurahan (Penagihan) melalui pembantu kolektor PBB (di berikan tanda lunas sementara dari DISPENDA KOTA BANDAR LAMPUNG).

6. Menghimbau kepada wajib pajak gologan besar, untuk membayar. Melalui pengajuan bulanan yang dipimpin oleh para Ulama, dengan menyelipkan dalam materi ceramahnya bahwa, membayar Pajak Bumi dan Bangunan adalah merupakan ibadah kepada Allah SWT.

7. Menghimbau melalui Pak RT (Rukun Tetangga) dengan pendekatan Persuasive dan bagi RT yang memenuhi target pencapaian pengumpulan $\mathrm{PBB}, \quad$ akan disusulkan langsung ke Walikota untuk mendapatkan Umroh secara gratis melalui program Bapak Walikota Bandar Lampung.

Straregi Lurah dalam mencapai Target Pengumpulan PBB, sudah sesuai dengan apa yang dijelaskan oleh ahli manajemen dan Organisasi Peter Dreker, dimana dikatakan fungsi pemimpin dalam 
berorganisasi dalam mencapai tujuan organisasi antara lain sebagai berikut:

1. Memotivator - (membangkitkan semangat kerja)

Seorang pemimpin harus dapat membangkitkan antusiasme untuk tugas organisasi. Pegawai harus merasa bahwa tugas-tugas ini sangat penting dan bahwa mereka harus benar-benar berminat akan pekerjaan mereka. Mereka harus senang dan bangga bila mereka mengusahakan yang tebaik yang dapat mereka kerjakan. Mereka harus mempunyai suatu dorongan untuk mendapatkan cinta dan kasih pemimpin mereka. Tugas utama pemimpin adalah menciptakan iklim antusiasme seperti itu.

2. Membangun Komunikasi (saling berinteraksi)

Dalam suatu organisasi, sejumlah besar ogang bekerja bersama. keputusan dan tindakan mereka terus menerus berinteraksi. Seringkali mereka mengalami konflik satu sama lain. Ini kembali merupakan tugas pemimpin untuk memahami sifat interaksi ini. Intergrasi akan bergantung kepada pengertian yang tepat akan sifat tugas-tugas yang berbeda, hubungan mereka, dan fungsi mereka.

3. Berintegrasi (menjalin setia/kekompakan terpadu)

Berinteraksi berarti menciptakan suatu keseluruhan dari sejamlah besar tindakan yang berlainan. Beberapa ribu bagian, bila dirakit dengan tepat menghasilkan mesin yang mengagumkan. Dalam suatu konser musik, mungkin terdapat sejumlah besar pemain musik. Konduktor korserlah yang menyusun dan menciptakan suatu keseluruhan yang harmonis dari jajaran nada yang membingungkan yang tersedia. Ia menggabungkan nada-nada tersebut dengan merdu, Ia menjamin urutan yang tepat dan gerakan yang berirama menuju suatu klimaks yang pas. Dengan dentikian ia mengintergrasikan. Pemimpin pun menciptakan suatu tim yang berfungsi secara energik, efisien, harmonis, dan setia.

4. Memunculkan Dinamisasi Organisasi (kondisi lapangan)

Memunculkan mengacu pada sifat dinamis manajemen. Organisasi yang baol tidak pernah statis karena organisasi berada dalam dunia yang berubah. Pasar berubah, teknologi berkembang, sikap dan cita-cita manusia menjalani perubahan halus sepanjang waktu. Seorang pemimpin harus memahami relevansi semua perubahan ini dan harus mengetahui bagaimana menghadapinya. Kondisi bisnis sering tidak menentu dan pemimpin harus mempunyai kemampuan menghadapi ketidakmenentuan ini.

5. Memahami manusia tidak sempurna (Selain Waspada)

Pemimpin harus merupakan penilai manusia yang baik. Ini merupakan tugas yang sangat sulit dan rumit. Penampilan sangat sangat menipu dan manusia terus berubah. Tidak ada jaminan bahwa seoran yang jujur akan terus jujur selama nya. Godaan banyak sekali dan bervariasi, dari uang, wanita, kekuasaan, dan sanjungan. Pemimpin tidak boleh menaruh rasa tidak percaya pada anak buahnya, tetapi sekaligus ia harus selalu waspada. Keputusan mengenai 
manusia sangat sulit dan harus selalu dibuat dengan hati hati.

6. Keberanian dalam mengambil keputusan (cekatan dan terampil)

Pemimpin akan selalu di tuntun oleh nilai-nilai dan prinsip-prinsip tertentu, Ia tidak akan pernah mengorbankan prinsip-prinsip ini. Bila perlu, ia dapat saja melepaskan posisi wewenangnya untuk mempertahankan Integritas dan nilai-nilai yang di anutnya. Tidak ada kepemimpinan sejati tanpa integritas. Seorang pemimpin yang berprinsip ia jujur dan berterus terang. Ia membenci manipulasi. Seseorang yang tidak jujur, betapapun berbakat nya akan menghancurkan organisasi tempatnya bekerja. Seperti yang dikatakan oleh Peter Drucker, "Pohon mati dari puncaknya", demikian pula organisasi. Banyak orang telah menghancurkan diri sendiri dan organisasi mereka karena tidak mempunyai integritas.

7. Mampu mengevaluasi (kemempuan dalam penilaian yang benar / objektif kepada bawahan

Pemimpin harus mempunyai penilaian yang kuat dan kemampuan untuk mencapai keputusan yang seimbang dan tepat. Manusia dapat saja berpengetahuan tinggi, tetapi ia mungkin tidak dapat melakukan penilaian. Penilaian bergantung kepada bebeapa faktor, seperti rasa tanggung jawab, kapasitas untuk mengabaikan apa yang tidak relevan, obyektivitas, dan tekad untuk mencapai keputusan yang tebaik dan kemampuan untuk menimbang dan mengimbangi. Untuk mengetahui apakah seseorang mempunyai penilaian yang kuat dibutuhkan waktu bertahun-tahun.

\section{Kepemimpinan}

\section{Konsep Kepemimpinan}

Kepemimpinan adalah hubungan yang ada dalam diri seseorang atau pemimpin, mempengaruhi orang lain untuk bekerja secara sadar dalam hubungan tugas untuk mencapai tujuan yang diinginkan (Sutarto, 1998 : 17 ). Kepemimpinan merupakan kemampuan untuk menciptakan kegiatan kelompok mencapai tujuan organisasi dengan efektifitas maksimum dan kerjasama dari tiaptiap individu (G.L. Feman \& E.K.aylor, 1950).

Kepemimpinan bisa juga diartikan sebagai keterampilan dan kemampuan seseorang mempengaruhi perilaku orang lain, baik yang kedudukannya lebih tinggi, setingkat maupun yang lebih rendah dari padanya dalam berpikir dan bertindak agar perilaku yang semula mungkin individualistic dan ego sentrik berubah menjadi perilaku organisasi (Sondang, 1985:12).

Kepemimpinan adalah suatu bentuk dominasi yang di dasari oleh kapabilitas atau kemampuan pribadi yaitu mampu mendorong dan mengajak orang lain untuk berbuat sesuatu guna mencapai tujuan bersama, Kepemimpinan tersebut juga berdasarkan pada penerimaan oleh kelompok dan kepemilikan keahlian khusus pada situasi khusus (Kartini Kartono, 2001:163).

Hemhill \& Coon mengatakan bahwa kepemimpinan adalah perilaku dari seseorang individu 
yang memimpin aktifitas-aktifitas suatu kelompok kesuatu tujuan yang ingin dicapai bersama (Hemhill \& Coon, 1995). Sedangkan William G. Scott mengatakan kepemimpinan adalah sebagai proses mempengaruhi kegiatan yang di organisir dalam kelompok di dalam usahanya mencapai suatu tujuan Yang telah ditentukan (William G. Scott, 1962). Kepemimpinan adalah cara mengartikulasikan visi, mewujudkan nilai, dan menciptakan lingkungan guna mencapai sesuatu (Yuki Gary, 2001:14).

Dari beberapa pendapat dari para ahli mengenai kepemimpinan, maka dapat disimpulkan bahwa kepemimpinan itu sebagai suatu interaksi antara seseorang dengan suatu kelompok, tepatnya antara seseorang dengan anggota-anggota kelompok setiap peserta didalam interaksi memainkan peranan dan dengan cara-cara tertentu peranan itu harus dipilah-pilahkan dari suatu dengan yang lain.

\section{Konsep Gaya Kepemimpinan}

Menurut William H.Newman (1968) dalam Thoha (2003:262) kepemimpiaan adalah kegiatan untuk mempengaruhi perilaku orang lain atau seni mempengaruhi perilaku manusia baik perorangan maupun kelompok. Dan satu hal yang pertu diingat bahwa kepemimpinan tidak harus dibatasi oleh aturan-aturan atau tata karma birokrasi. Kepemimpinan bisa terjadi dimana saja, asalkan seseorang menunjukkan kemampuannya mempengaruhi perilaku orang lain kearah tercapainya suatu tujuan tertentu.
Unsur yang saling terkait satu dengan lainnya, dan akan menentukan tingkat keberhasilan kepemimpinan.

3. Macam-Macam Pemikiran Gaya Kepemimpinan

Ada beberpa jenis gaya kepemimpinan yang di tawarkan oleh para pakar leardership, mulai dari yang klasik sampai kepada yang modern yaitu gaya kepemimpinan situasional model Hersey dan Blancard.

Teori klasik gaya kepemimpinan mengemukakan, pada dasarnya di dalam setiap gaya kepemimpinan terdapat 2 unsur utama, yaitu Unsur pengarahan (directive behavior) dan unsur bantuan (supporting behavior). Dari dua unsur tersebut gaya kepemimpinan dapat dikelompokkan Menjadi 4 kelompok, yaitu otokrasi (directing), pembinaan (coaching), demokrasi (suppporting), dan kendali bebas (delegating). Mengambil contoh pemimpin negara kita, presiden Susilo Bambang Yudhoyono.

\section{METODE PENELITIAN}

Penelitian merupakan suatu cara ilmiah yang digunakan untuk mendapatkan data dengan tujuan untuk menemukan jawaban, untuk membuktikan sesuatu hal untuk memecahkan masalah Adapun penelitian ini menggunakan metode kuantitatif, dimana merupakan metode analisis yang dilakukan terhadap data yang diperoleh dari hasil jawaban kuesioner yang digunakan untuk menganalisis data yang berbentuk angka-angka, Arikunto(2002.144).

\section{A. Teknik Pengumpulan Data}


Untuk mengumpulkan data yang diperlukan penulis menggunakan atau menempuh cara sebagai berikut:

1. Untuk memperoleh data sekunder, penulis mengadakan studi kepustakaan dengan cara membaca, mencatat / mengutip dari bukubuku atau referensi yang ada kaitannya dengan permasalahan yang sedang dibahas, dalam hal ini masalah kepemimpinan kepala sekolah dan kinerja staf tata usaha.

2. Untuk mendapatkan data primer, penulis mengadakan studi lapangan, adapun metode yang dipakai dalam mendapatkan data primer ini penulis menggunakan cara-cara sebagai berikut:

a. Observasi / pengamatan langsung : penulis mengumpulkan

data/keterangan mengenai strategi lurah dalam peningkatan pencapaian Pajak Bumidan Bangunan.

b. Quesioer : penulis menyusun sejumlah angket kemudian dibagikan kepada responden sebagai sampel.

\section{B. Populasi dan Sampel}

\section{Populasi}

Populasi adalah keseluruhan subyek daripenelitian. (Arikunto, 1998:115). Sedangkan menurut pendapat lain populasi adalah jumlah keseluruhan dari unit analisa yang cirinya akan diduga (Singarimbun, 1995:152).

Dari dua pendapat diatas dapat ditarik kesimpulan, bahwa populasi adalah seluruh subjek yang menjadi sasaran dalam suatu penelitian adapun yang menjadi populasi dalam penelitian ini adalah seluruh pegawai di Kelurahan Way Dadi Kecamatan Sukarame Bandar Lampung, Sebanyak 12 orang.

\section{Sampel}

Sampel adalah sebagian atau wakil populasi yang diteliti. (Arikunto, 1998 :177). Sedangkan pendapat lain menyatakan salah satu hal yang menakjubkan dalam penelitian ini adalah kenyataan bahwa kita dapat menduga sifat-sifat suatu obyek penelitian hanya dengan mempelajari dan mengamati sebagian dari kumpulan itu. Selanjutnya, dikarenakan subjek penelitian berjumlah kurang dari 100 orang, maka seluruh populasi penelitian sejumlah 12 orang diambil sebagai sampel.

\section{Metode Pengolahan Data}

Dalam mengolah data, digunakan teknik sebagai berikut:

1. Editing, yaitu memeriksa kelengkapan data, kejelasan, dan relevansinya dengan permasalahan yang dibahas.

2. Coding, yaitu pengelompokan jawaban yang terkumpul dalam pokok-pokok bahasan yang akan dilaksanakan

3. Interpretasi data, yaitu mendeskripsikan data melalui tabel atau narasi dan diinterpretasikan untuk dianalisa

4. Evaluating, yaitu evaluasi data untuk menjamin kebenaran

\section{Analisa Data}

Proses analisa data yang dilakukan dalam penelitian ini, antara lain: 
1. Membuat catatan lapangan dilengkapi dengan kode-kode agar sumber data dapat ditelusuri

2. Mengumpulkan, memilah, mengklasifikasi, mensintesiskan, membuat ikhtisar, dan membuat indeks data

3. Mencari dan menentukan pola dan hubungan-hubungan antar data, serta membuat temuan-temuan

\section{PEMBAHASAN}

\section{A. Hasil Penelitian}

Metode yang digunakan dalam penelitian ini adalah metode kuantitatif, dimana metode ini digunakan untuk menganalisa data berbentuk angka.

Salah satu rumus yang diperlukan dalam proses analisa data adalah rumus untuk mencari nilai Interval, yaitu:

$$
I=\frac{N T-N R}{K}
$$

Keterangan :

$$
\begin{array}{ll}
\text { I } & \text { : Internal } \\
\text { NT } & \text { : Nilai Tertinggi } \\
\text { NR } & \text { : Nilai Terendah } \\
\text { K } & \text { : Kategori }
\end{array}
$$

(Hadi, 1986 : 6)

Berdasarkan rumus tersebut, maka nilai interval diketahui sebesar 16,6. Dengan rincian skor tertinggi 75 dan skor terendah 25. Sementara kategori terdiri dari:

a. Alternatif jawaban A diberi nilai 3

b. Alternatif jawaban B diberi nilai 2

c. Alternatif jawaban C diberi nilai 1

Dengan nilai interval 16,6, maka didapatkan:
a. Kriteria Baik : $58,4 \quad-$ 75
b. Kriteria Cukup Baik : 41,7 - 58,3
c. Kriteria Tidak Baik : 25 - 41,6

Setelah pengumpulan data variabel $\mathrm{X}$ dan $\mathrm{Y}$ dilakukan, hasil perhitungan data tersebut kemudian dimasukkan ke dalam tabel koefisien korelasi product moment, sebagai berikut:

Tabel 4.21. Tabel Penolong untuk menghitung koefisien korelasi Product Moment

\begin{tabular}{|c|c|c|c|c|c|}
\hline No & $\mathrm{X}$ & $\mathrm{Y}$ & $\mathrm{X}^{2}$ & $\mathrm{Y}^{2}$ & $\mathrm{XY}$ \\
\hline 1 & 26 & 26 & 676 & 676 & 676 \\
\hline 2 & 28 & 29 & 784 & 841 & 812 \\
\hline 3 & 26 & 27 & 676 & 729 & 702 \\
\hline 4 & 26 & 27 & 676 & 729 & 702 \\
\hline 5 & 27 & 25 & 729 & 625 & 675 \\
\hline 6 & 22 & 23 & 484 & 529 & 506 \\
\hline 7 & 24 & 24 & 576 & 576 & 576 \\
\hline 8 & 27 & 29 & 729 & 841 & 783 \\
\hline 9 & 25 & 25 & 625 & 625 & 625 \\
\hline 10 & 25 & 26 & 625 & 676 & 650 \\
\hline 11 & 22 & 23 & 484 & 529 & 506 \\
\hline 12 & 24 & 24 & 576 & 576 & 576 \\
\hline Jumlah & 280 & 285 & 7156 & 7423 & 7283 \\
\hline
\end{tabular}

Ket :

$\mathrm{X}=$ Skor

$\mathrm{Y}=$ Skor

$\mathrm{N} \quad=12$

$\sum X=280$

$\sum \mathrm{Y}=285$

$\sum X^{2}=7156$

$\sum \mathrm{Y}^{2}=7423$

$\sum X Y=7283$

$\sum(\mathrm{X})^{2}=78400$

$\sum(\mathrm{Y})^{2}=81225$ 


$$
\begin{aligned}
& r_{x y}=\frac{\mathrm{n} \cdot\left(\sqrt{\sum \mathrm{XY}}\right)-\left(\sum \mathrm{X}\right) \cdot\left(\sum \mathrm{Y}\right)}{\sqrt{\left\{\mathrm{n} \cdot \sum \mathrm{x}^{2-\left(\sum \mathrm{x}\right)^{2}}\right\}\left\{\mathrm{n} \cdot \sum \mathrm{Y}^{2-}\left(\sum \mathrm{Y}\right)^{2}\right\}}} \\
& =\frac{11 \cdot(7283)-(280) \cdot(285)}{\sqrt{\left(11 \cdot(7156)-(280)^{2}\right) \cdot\left(11 \cdot(7423)-(285)^{2}\right)}} \\
& r=\frac{80113-79800}{\sqrt{(78716-78400) \cdot(81653-81225)}} \\
& r=\frac{313}{\sqrt{(316) \cdot(428)}} \\
& r=\frac{313}{367,76} \\
& r=0,851
\end{aligned}
$$

Berdasarkan perhitungan diatas, diketahui $\mathrm{r}$ hitung $=0,851$, dan $\mathrm{r}$ tabel $=$ 0,602 maka terdapat hubungan antara strategi lurah dalam peningkatan pencapaian pajak bumi dan bangunan yang sangat kuat. Hal ini sejalan dengan pendapat Sugiyono (2011:184) bahwa koefisien kolerasi tersebut berada pada interval koefisien. 0,8 - 1,0 dan termasuk tingkat hubungan yang sangat kuat.

Selanjutnya untuk melihat besarnya pengaruh diperoleh dari besarnya koefisien penentu (Kp). Kp $=0,851^{2}$ x 100\% dengan demikian besarnya Kp adalah $72,4 \%$ hal ini berarti $72,4 \%$ peningkatan pajak bumi dan bangunan ditentukan oleh strategi lurah, sisanya sebesar $27,6 \%$ ditentukan oleh faktor lain.

\section{B. Uji Hipotesis}

Selanjutnya untuk menguji hipotesis dilanjutkan dengan uji t, hasil uji $\mathrm{t}$ adalah sebagai berikut:

$$
\begin{aligned}
& t=\frac{r \cdot \sqrt{\mathrm{n}-2}}{\sqrt{1-\mathrm{r}^{2}}} \\
& t=\frac{0,851 \cdot \sqrt{11-2}}{\sqrt{1-0,851^{2}}}
\end{aligned}
$$

$t=\frac{0,851 \cdot \sqrt{9}}{\sqrt{1-0,724}}$

$t=\frac{0,851 \times 3}{\sqrt{0,724}}$

$t=\frac{2,553}{0,525}$

$t=4,863$

Hipotesis yang diajukan adalah :

Ho : tidak ada pengaruh strategi lurah dalam peningkatan pencapaian pajak bumi dan bangunan

H1 : ada pengaruh-pengaruh strategi lurah dalam peningkatan pencapaian pajak bumi dan bangunan

Kriteria pengujian hipotesisnya adalah :

1) Jika $\mathrm{t}$ hitung $\geq \mathrm{t}$ tabel $(\alpha 0,05 \mathrm{dk}=$ n-2), maka Ho ditolak dan H1 diterima

2) Jika t hitung $<\mathrm{t}$ tabel $(\alpha 0,05 \mathrm{dk}=$ n-2), maka Ho diterima dan $\mathrm{H} 1$ ditolak.

Berdasarkan hasil perhitungan diperoleh $\mathrm{t}$ hitung $=4,863$ sedangkan $\mathrm{t}$ tabel $(\alpha 0,05 \mathrm{dk}$ $=9$ ) adalah 1,83. Karena nilai $\mathrm{t}$ hitung $(4,863)>\mathrm{t}$ tabel $(1,83)$ maka Ho ditolak. Dan H1 diterima. Dengan demikian dapat disimpulkan ada pengaruh strategi lurah dalam peningkatan pencapaian pajak bumi dan bangunan pada kelurahan Way Dadi Kecamatan Sukarame Bandar Lampung.

\section{KESIMPULAN DAN SARAN}

\section{A. Kesimpulan}

1. Lurah harus memiliki strategi yang tepat dalam meningkatkan pencapaian Pajak Bumi dan Bangunan

2. Berdasarkan perhitungan diatas, diketahui $\mathrm{r}$ hitung $=0,851$, dan $\mathrm{r}$ tabel $=0.602$, maka terdapat 
hubungan antara Strategi Lurah dalam peningkatan yang sangat kuat. Hal ini sejalan dengan pendapat Sugiyono (2011.184) bahwa koefisien korelasi tersebut berada pada interval koefisien $0,8-$ 1,0 dan termasuk tingkat hubungan yang sangat kuat.

3. Sarana dan prasarana yang dimiliki kelurahan Way Dadi Bandar Lampung dapat menunjang terlaksananya tugas dan fungsi staf kelurahan.

4. Pengumpulan, penyimpanan data, dan dokumen yang dapat dipergunakan untuk membantu pimpinan dalam pengambilan keputusan, urusan surat menyurat serta laporan mengenai kegiatan kelurahan.

\section{B. Saran}

1. Lebih meningkatkan sarana dan prasarana Kelurahan guna lebih meningkatkan prestasi atau mutu Kelurahan Way Dadi Bandar Lampung.

2. Lebih meningkatkan ketrampilan yang dmiliki staf Kelurahan Way Dadi Bandar Lampung, agar dapat melaksanakan tugas dan fungsi staf tata usaha lebih baik lagi.

3. Mengayomi masyarakat hingga merasa tidak terbebani dengan adanya pembayaran PBB.

\section{DAFTAR PUSTAKA}

AB., Susanto, 1996. Keputusan dan Loyalitas Konsumen. Bisnis Indonesia, Jakarta

Arikunto, Suharsini, 1997. Prosedur Penelitian. Rineka Cipta, Jakarta

Arikunto, Suharsini, 2004. Prosedur Penelitian, Edisi Revisi. PT. Bina Aksara, Jakarta
Arikunto, Suharsini, 1987. Methodology Research. UGM, Yogyakarta

Cushway, Barry, 1996. Human Resource Management (Manajemen SDM). Gramedia, Jakarta

Cushway, Barry, 1987. Methodology Research. UGM, Yogyakarta

Djamil, 2003. Pengembangan Pegawai. Ghalia Indonesia, Jakarta

Husnan, 2003. Manajemen Personalia, Ghalia Indonesia, Jakarta

Malayu SP., Hasibuan, 2005. Manajemen: Dasar, Pengertian dan Masalah. Bumi Aksara, Jakarta

Manulang, M., 1989. Pengembangan Pegawai. Ghalia Indonesia, Jakarta

Manulang, M., 2003. Manajemen Personalia. Gajah Mada University Press, Yogyakarta

Meokijat, 1992. Manajemen Kepegawaian. Mandar Maju, Bandung

Nawawi, Hadari, 1991. Metode Penelitian Bidang Sosial. Gajah Mada University Press, Yogyakarta

Patton, 2000. Metodologi Penelitian Kualitatif. Salemba Universitas Indonesia, Jakarta

Poerwadarminta, WJS., 1981. Kamus Besar Bahasa Indonesia

Sarwoto, 1990. Dasar-Dasar Organisasi dan Manajemen. Ghalia Indonesia, Jakarta

Supranto, J., 1991. Metode Penelitian dan Aplikasinya dalam Pemasaran. Universitas Indonesia, Jakarta 
Suhardi, 2000. Manajemen Kepegawaian di

Indonesia. Gunung Agung, Jakarta

Rahman, 2003. Manajemen Personalia.

Ghalia Indonesia, Jakarta 